\title{
GUIDE TO CONTRIBUTORS
}

THESE notes supersede those published in JHS lxxxix (1969) $1-6$. Please adhere to the conventions below: contributions which do not may be returned by the Editors for retyping.

\section{Presentation of manuscripts}

Contributions should be typed in double spacing on one side of the paper only, with ample margins on all sides. Footnotes should be typed on separate sheets, and numbered consecutively.

Copy must be clean and carefully revised. Please avoid overtyped letters and handwritten corrections and additions. Greek should be typewritten if possible, or xeroxed from a clear text. If handwritten, it must be clear enough to be set accurately by Greekless compositors.

Good photocopies of typescripts or good quality print-outs from a word-processor should be submitted: rejected submissions will not be returned to an overseas address unless postage is met by the author.

\section{Transliteration of Ancient Greek names}

Authors may follow their preference provided that they attempt consistency: thus Bocotia and Dicaearchus or Boiotia and Dikaiarchos/Dikaiarkhos. Names very familiar in a latinised or anglicised form may be so retained, e.g. Plato rather than Platon, whichever system is adopted.

\section{Style of references}

Economy and clarity are the aim of the following conventions.

Ancient texts. Abbreviations should generally be those of Liddell and Scott (9th edition) and the Oxford Latin Dictionary, but deviations in the interests of intelligibility are acceptable, e.g. Aesch., Eur., Soph. rather than A., E., S.

References should be in the following form:

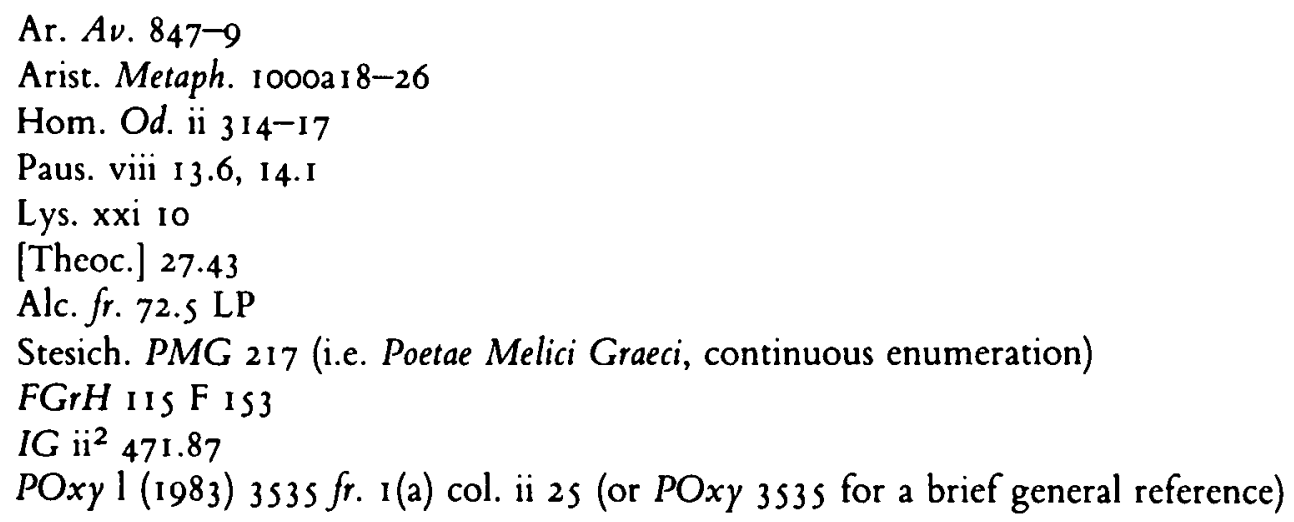

Note that numbers of books and speeches are in lower case roman, poems and chapters in arabic (followed by a full point and line or section number if applicable).

Modern works. For all except the most standard works author's initials and place and date of publication should be given in a footnote at the first citation. In the case of articles the title may be quoted if it is helpful. Subsequent citations should refer back to the first in the following way: Easterling (n. 21) $5 \mathrm{I}^{-6}$ (not Easterling op. cit. $\mathrm{s}_{\mathrm{I}}-6$ ). A short title or date of publication should be appended to the surname if more than one work by the same author is listed in the footnote cited. Where a work is very frequently cited an abbreviation should be announced in the first footnote, and subsequent references should be in the form Momigliano Io6 (with no comma separating surname from page number). 


\section{GUIDE TO CONTRIBUTORS}

Widely accepted abbreviations of book titles may be used, e.g. $O C D^{2}$. Abbreviations of periodicals should in the main follow L'année philologique, but may be expanded to avoid obscurity.

References should be in the following form:

P. M. Fraser, Ptolemaic Alexandria ii (Oxford 1972) I92 n. 88

J. Fontenrose, Orion: the myth of the hunter and the huntress, U. Cal. Publ. in Classics xxxiii (I98I) $25-7$

A. A. Long, 'Morals and values in Homer', JHS xc (1970) I 21,127

AthMitt lxvi (1941) 35, pl. I I.4I6; but (AthMitt lxvi [194I] 35, pl. I1.4I6)

$R E$ suppl. x (1968) s.v. 'Lykophron' 888-930, or $R E$ suppl. xi (1968) 888-930.

Note that titles of books and periodicals should be underlined for italics; titles of articles or chapters should be enclosed in single inverted commas. Titles should not be capitalised: thus Polarity and analogy, not Polarity and Analogy.

Volume numbers are in lower case roman, followed in the case of periodicals by the year in parentheses and the page reference. For those periodicals where no volume number is normally used, a comma separates the year without parentheses from the page reference, c.g. $R A$ i 976 , $205-18$. Where fascicle numbers are necessary they follow the volume number after a full point, e.g. xvii.2 (1972) 16-18.

Editions subsequent to the first are indicated by a superscript number attached to the title, e.g. E. R. Dodds, Euripides, Bacchae ${ }^{2}$ (Oxford 1960).

Reference to page numbers should be made by number only, unless ' $\mathrm{p}$.' is necessary to avoid confusion.

n., nn. = note(s); no., nos = number(s). Pl., pls and fig., figs are used to refer to plates and figures in other publications; illustrations accompanying the article are referred to by PLATE I, II etc., and FIG. I, 2 etc.

\section{Quotations}

Quotations in English and foreign languages in the roman alphabet should be enclosed in single inverted commas, a quotation within a quotation in double inverted commas. Where the passage exceeds a few lines it may be set without quotation marks as an indented paragraph.

Quotations of a few words in Latin may be underlined for italics, e.g. Livy xlii 51.3 pars ferme dimidia.

Square brackets should enclose material inserted in quotations, e.g. 'She [Pandora] reveals...'

Where a quotation forms part of an author's sentence punctuation should fall outside the inverted comma closing the quotation, e.g. an example of 'multiple approaches', but since ...

\section{Miscellaneous points of style}

Square brackets should be used for parentheses within parentheses. c., fr., sc., id., ibid., loc. cit., $o p$. cit. should be underlined for italics. of. should be underlined unless followed immediately by an italicised word, e.g. $f$. Pritchett 20 , but cf. fr. 64 .

i.e. and e.g. are not italicised, nor is s.v., which should be followed by the word quoted in single inverted commas.

$B C$ and $A D$, without points, should follow the date. 


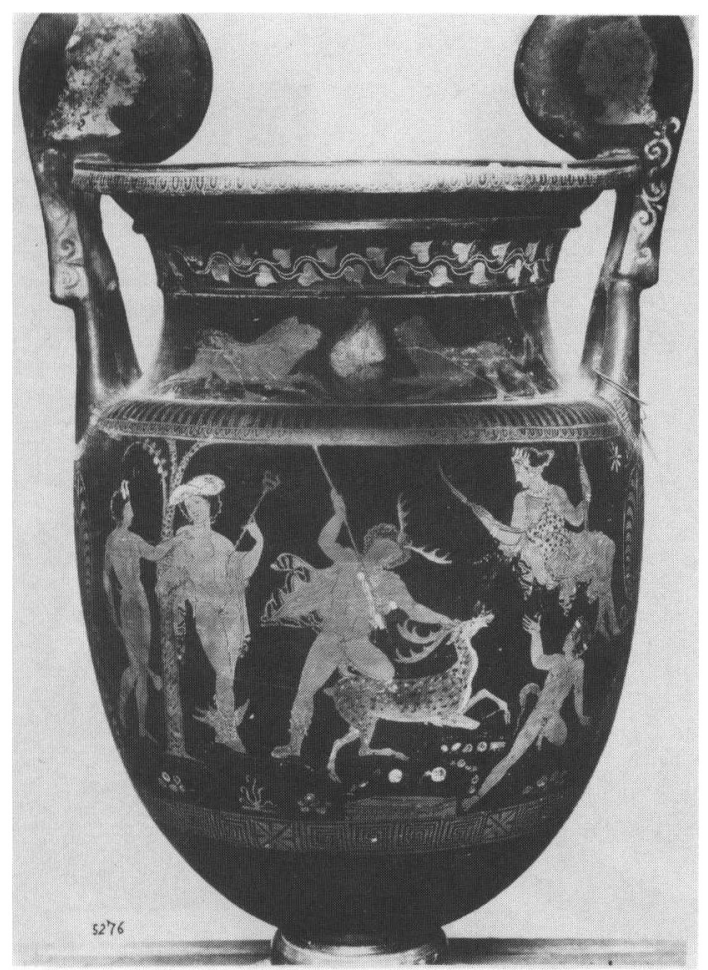

(a) Apulian red-figured volute-krater, Naples SA 3I. Photo National Archaeological Museum neg. MN/B994.1928.

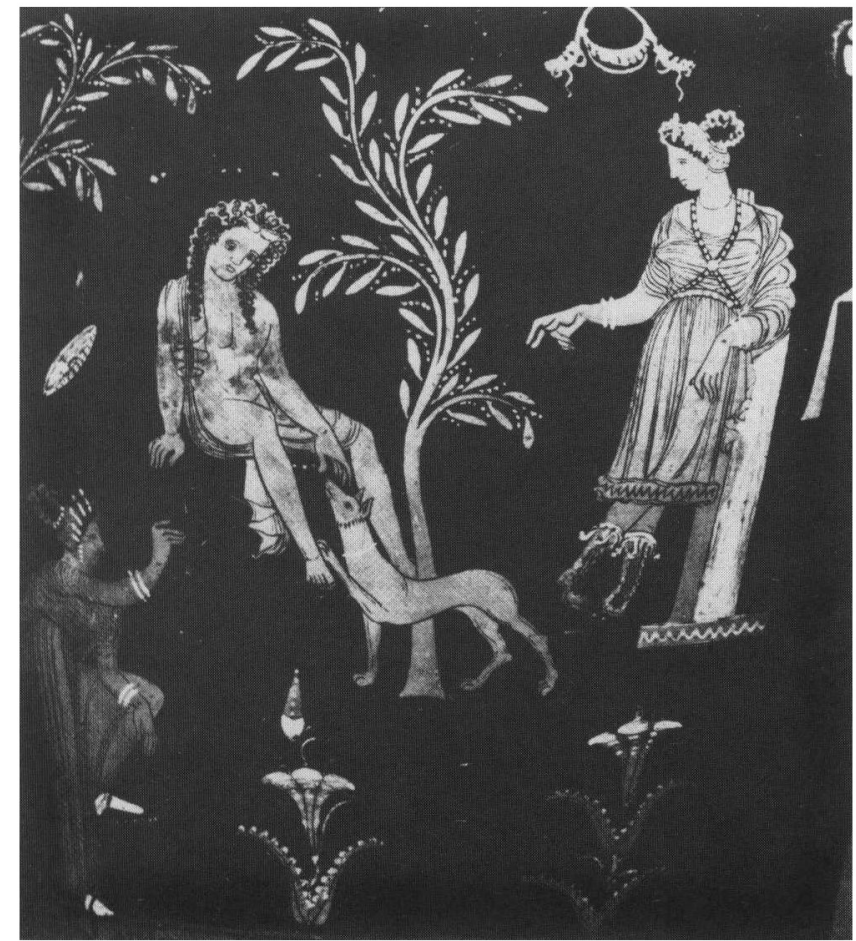

(b) Apulian red-figured stamnos, Paris, Bibliothèque Nationale 949. Photo from Kossatz pl. 30.2. 

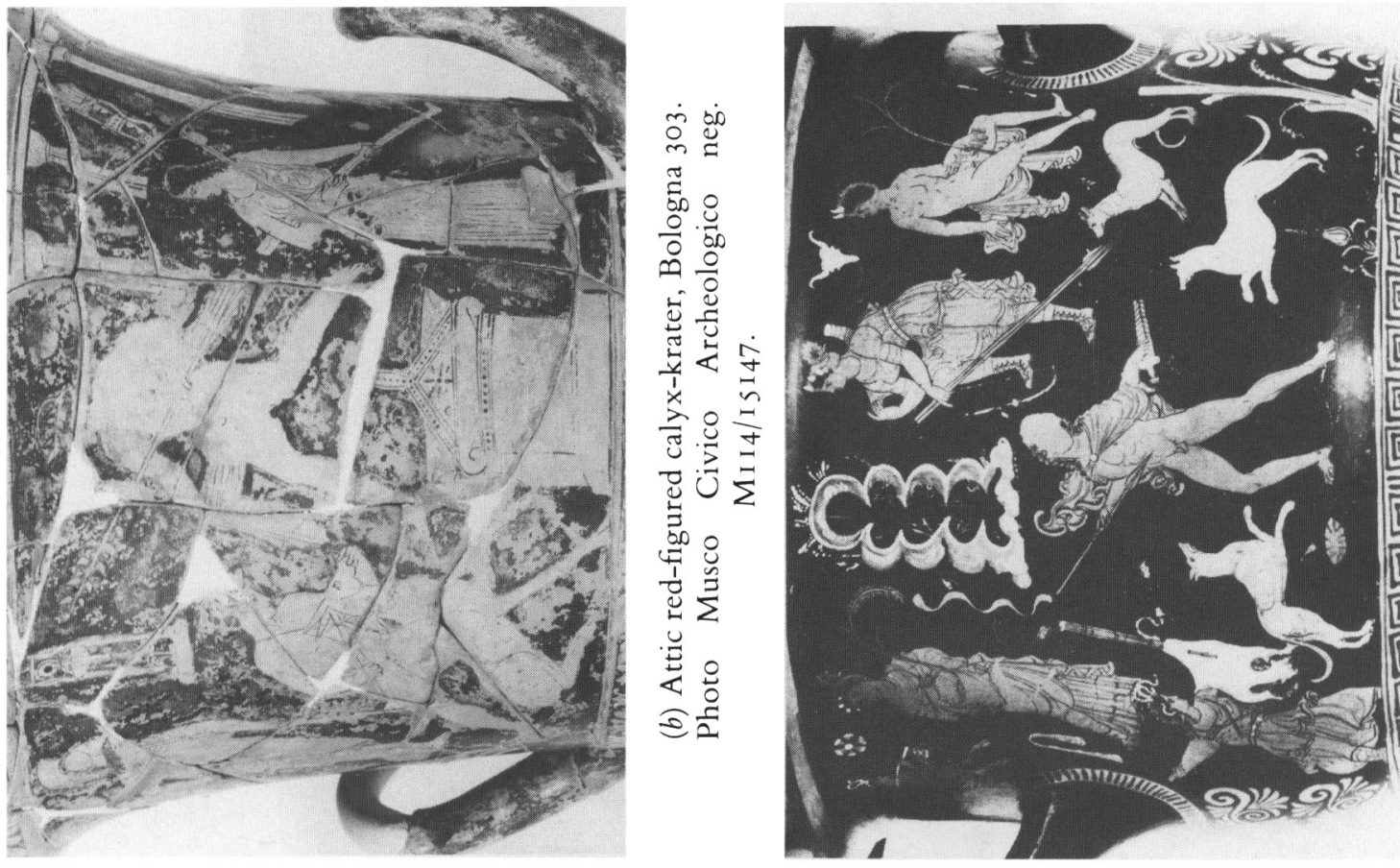

焉

要

京京

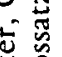

焉

总

은

$\underbrace{200}_{0}$

它部

羊

总文

$\Xi$

昰

4

岁

5

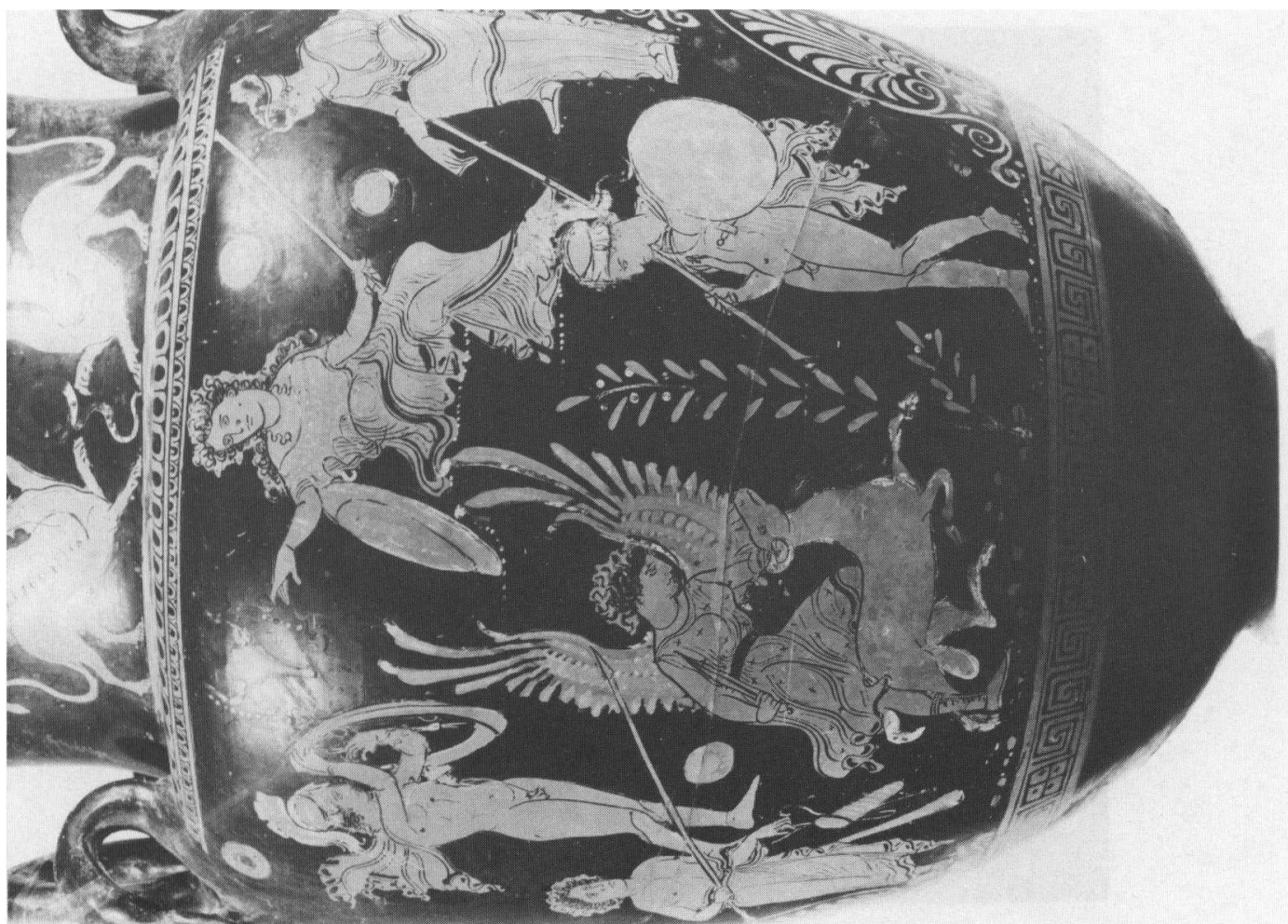

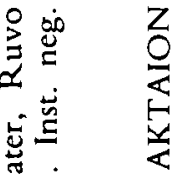




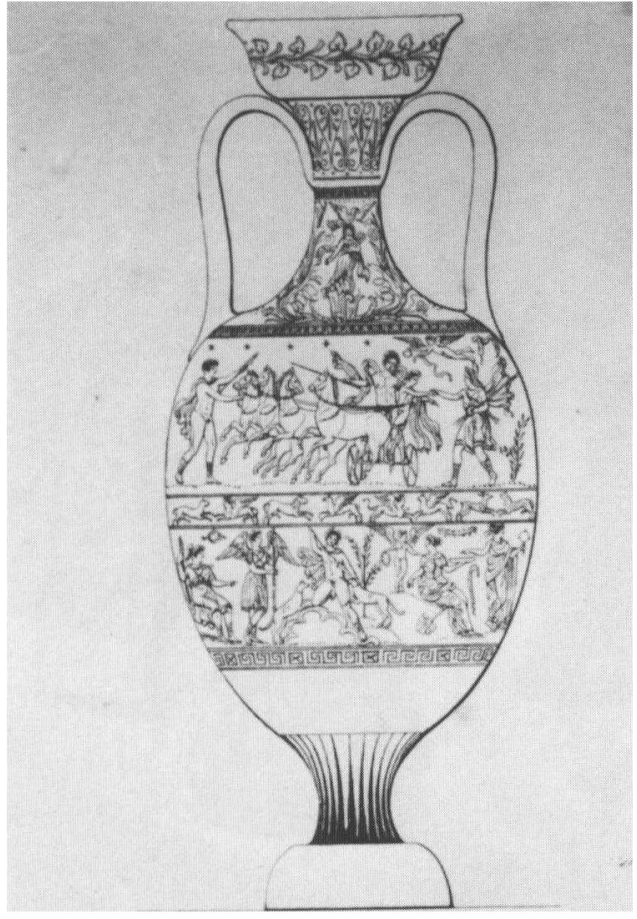

(a)

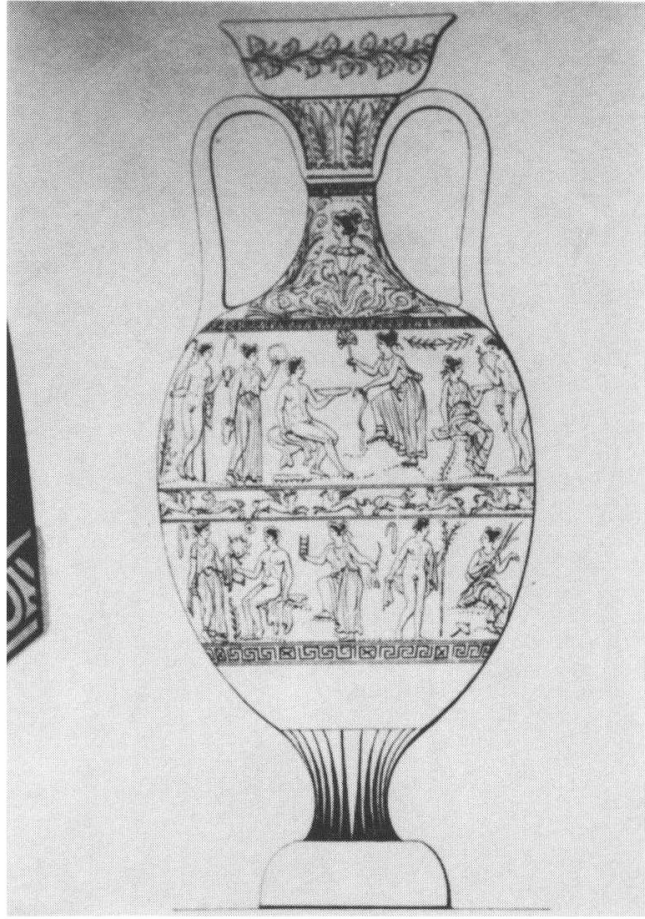

(b)

(a) $\mathcal{E}$ (b) Apulian red-figured amphora, Berlin, Pergamonmuseum F 3239. Photos from E. Gerhard, Apulische Vasenbilder des Königlichen Museums zu Berlin (Berlin I 845) pl. 6.

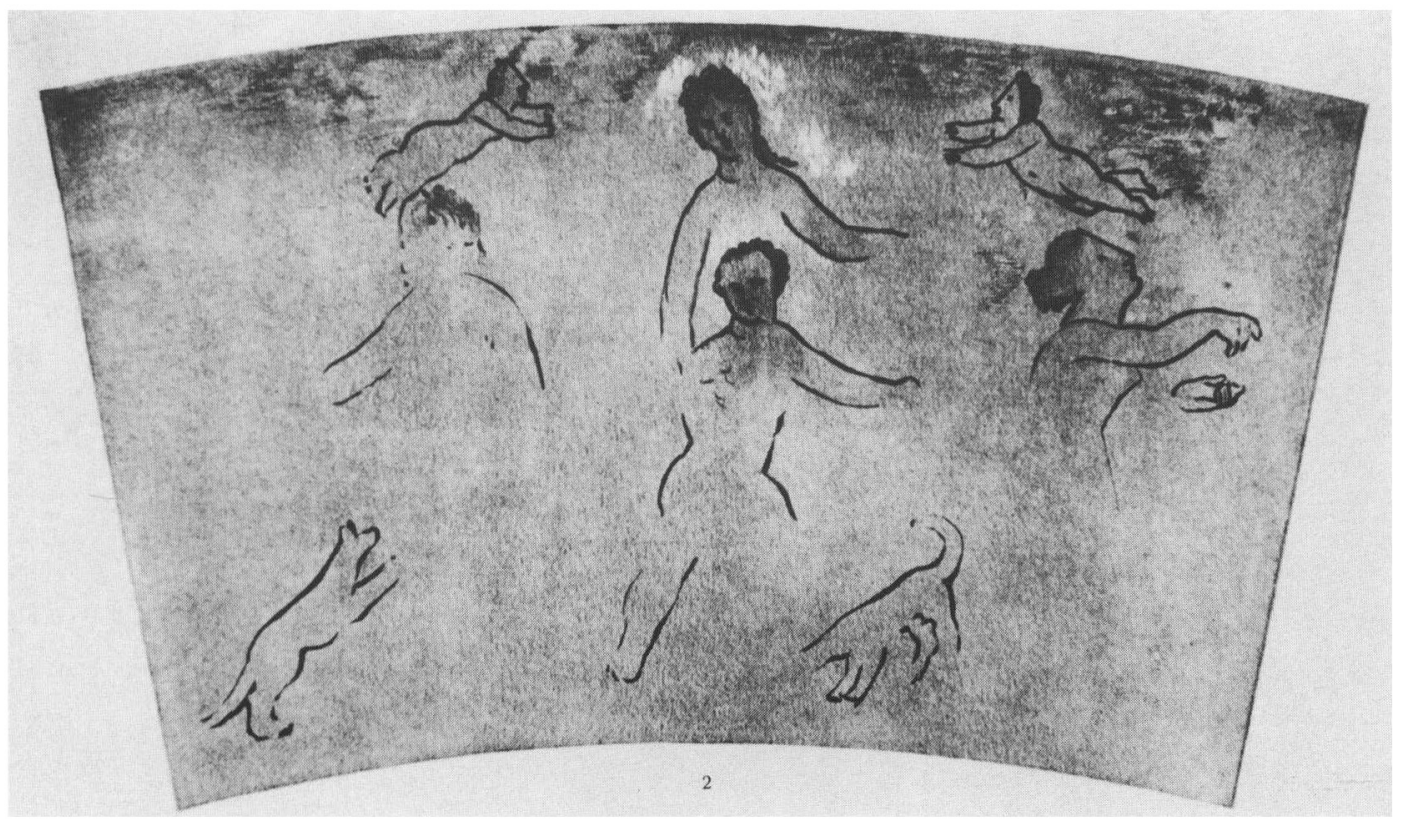

(c) Campanian pyxis, Naples I28525. Photo from MonAnt 22.2 (I9I3) pl. I20.2. 


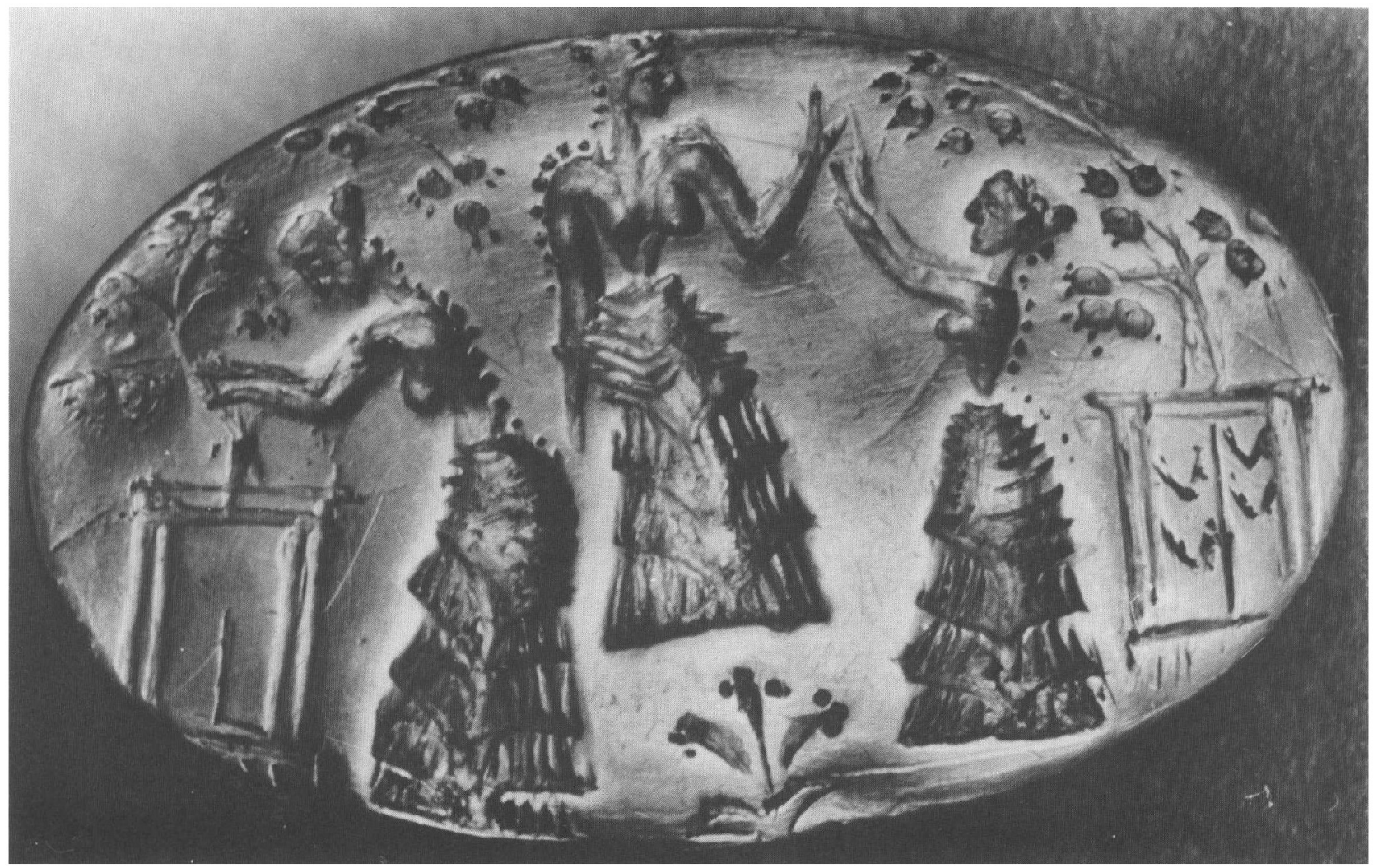

(a) CMS II.3.326.

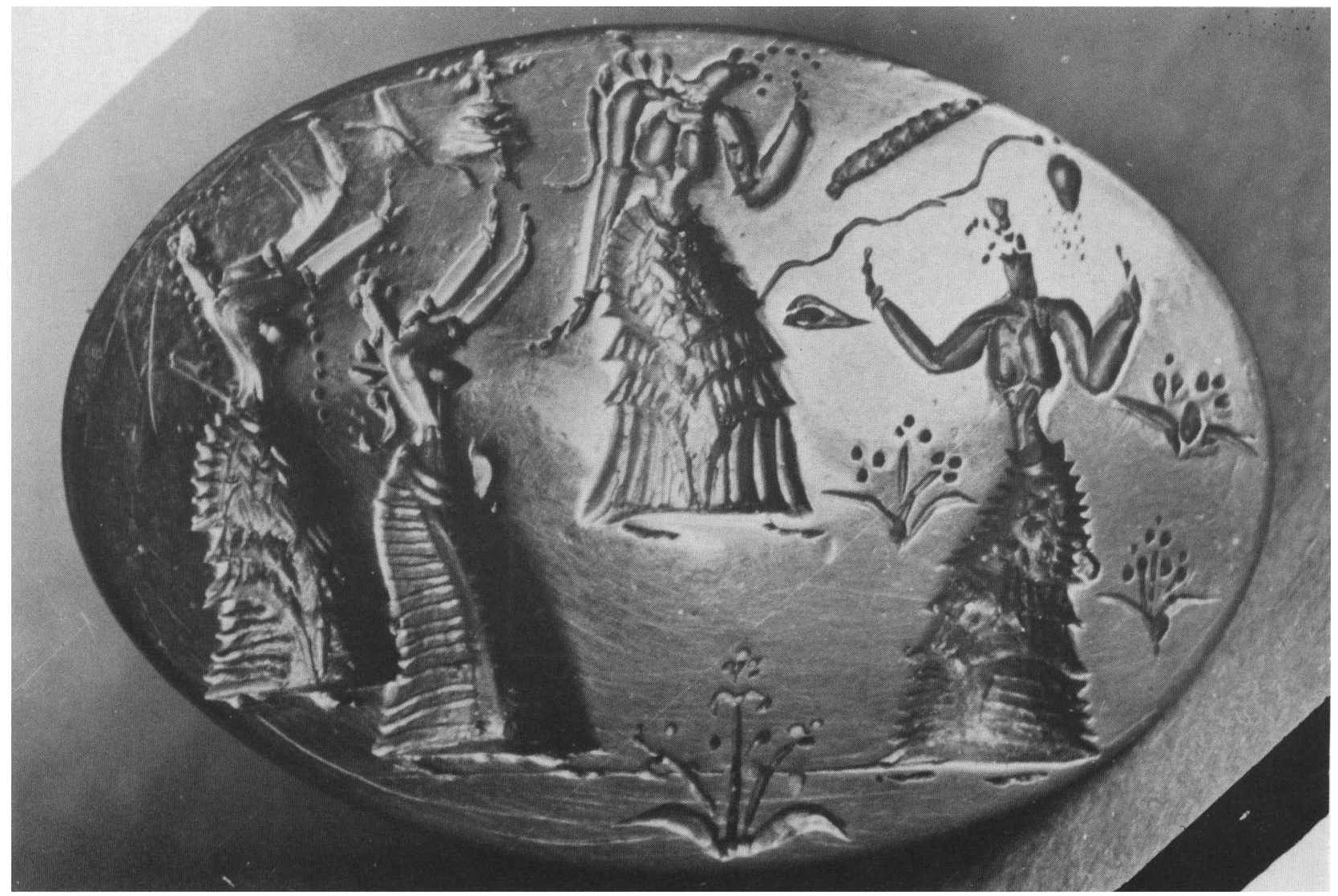

(b) CMS II.3.5I.

AGAINST THE AUTHENTICITY OF THE RING CMS II.3.326 


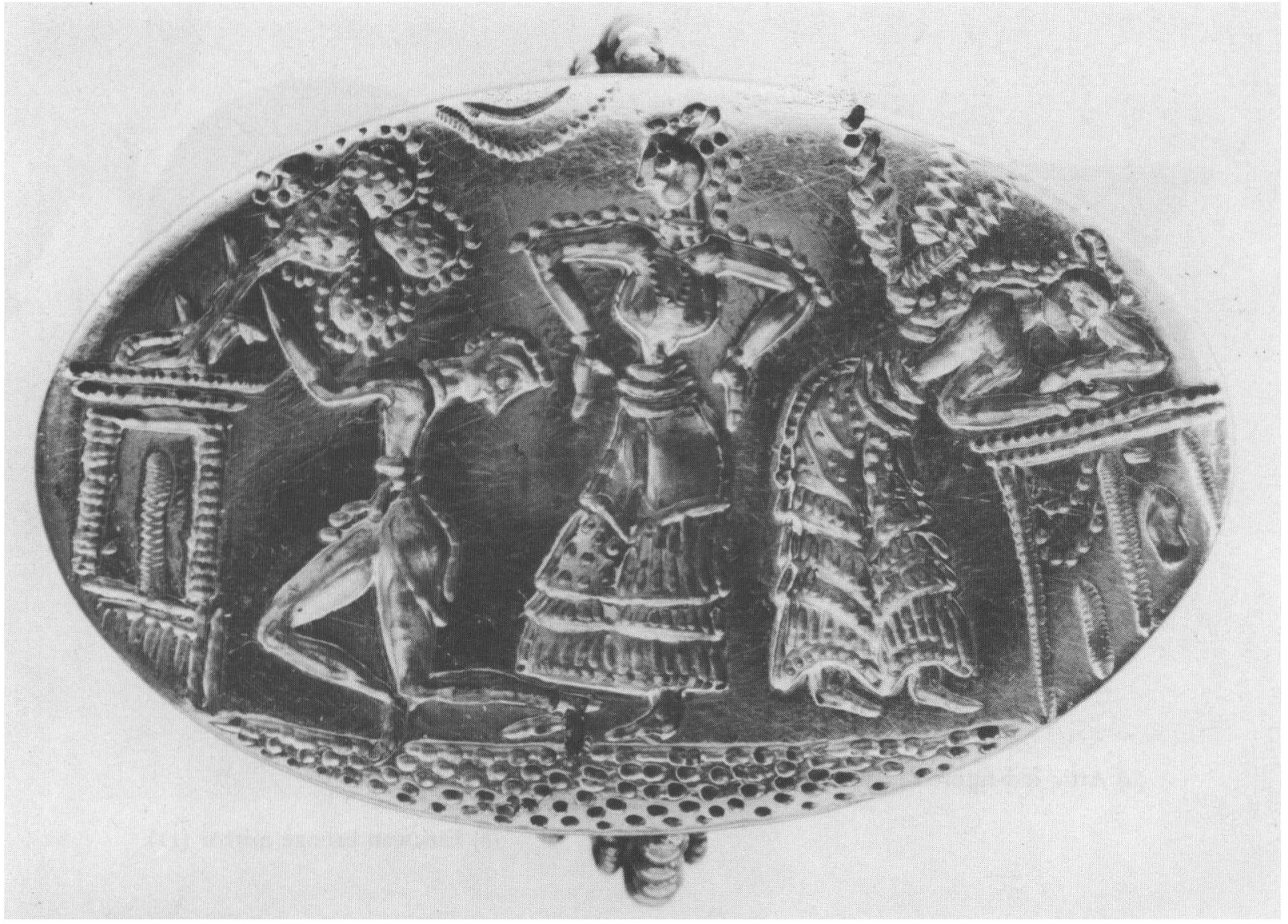

(a) CMS I. I 26.

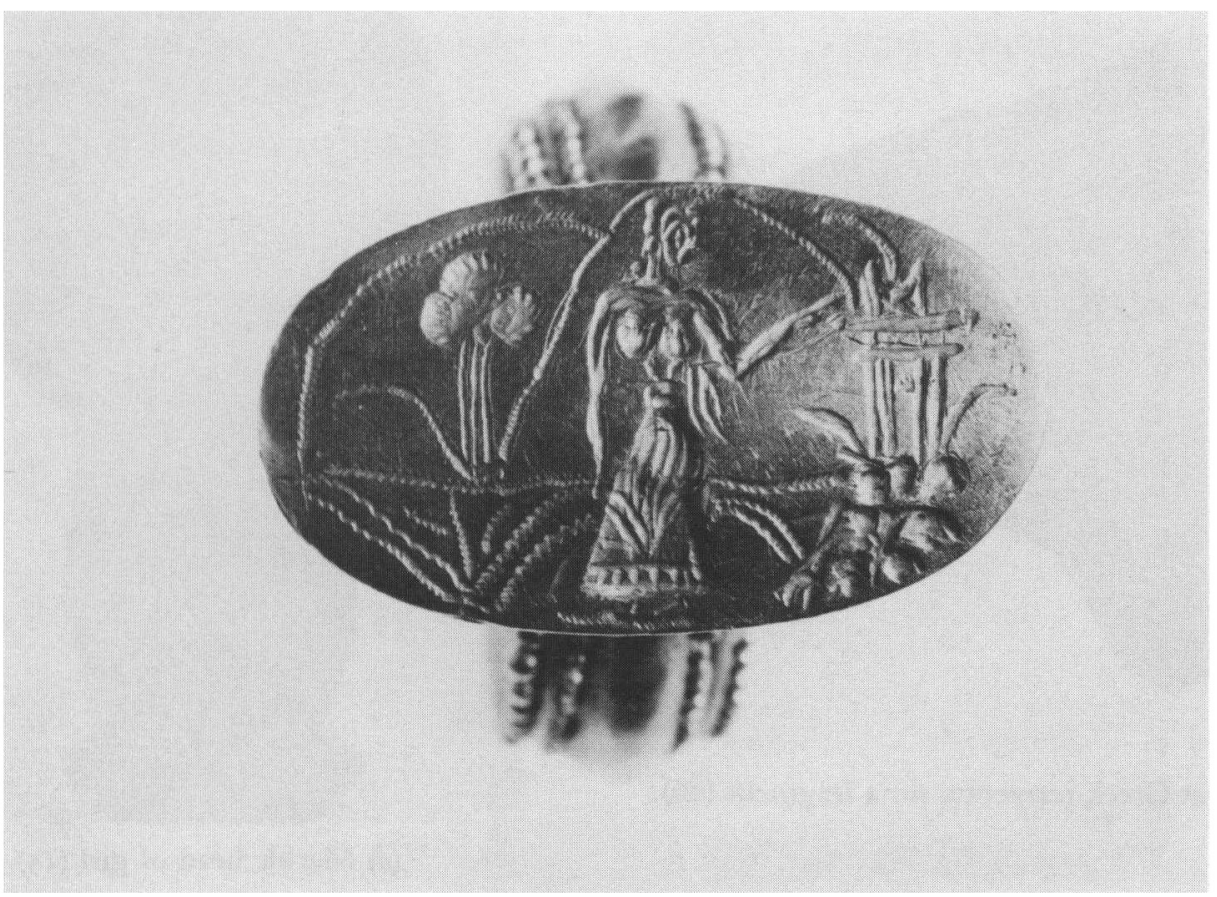

(b) A.M. I938. I 28. 


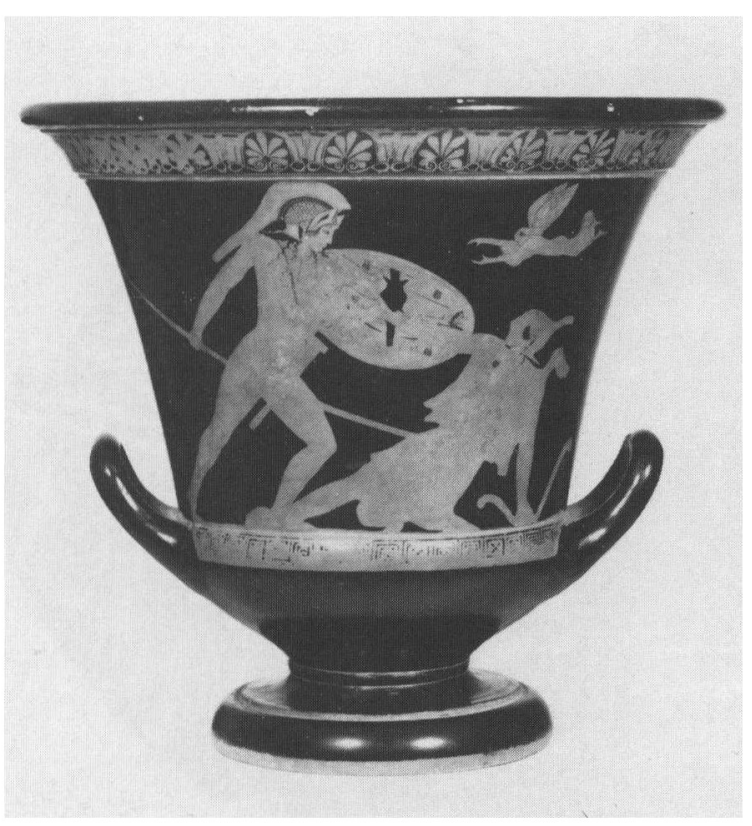

(a) Attic red-figured calyx-krater (I 8).

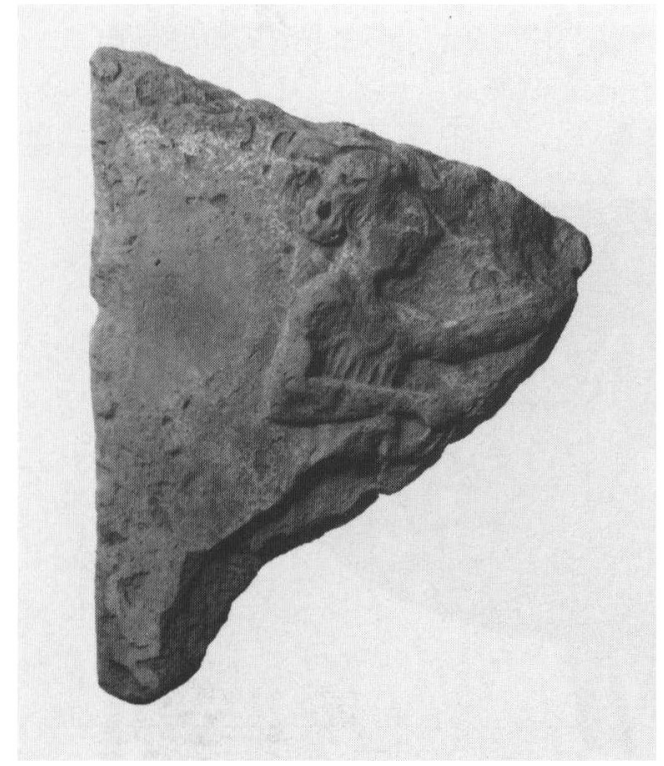

(c) East Greek terracotta sima fragment (26).

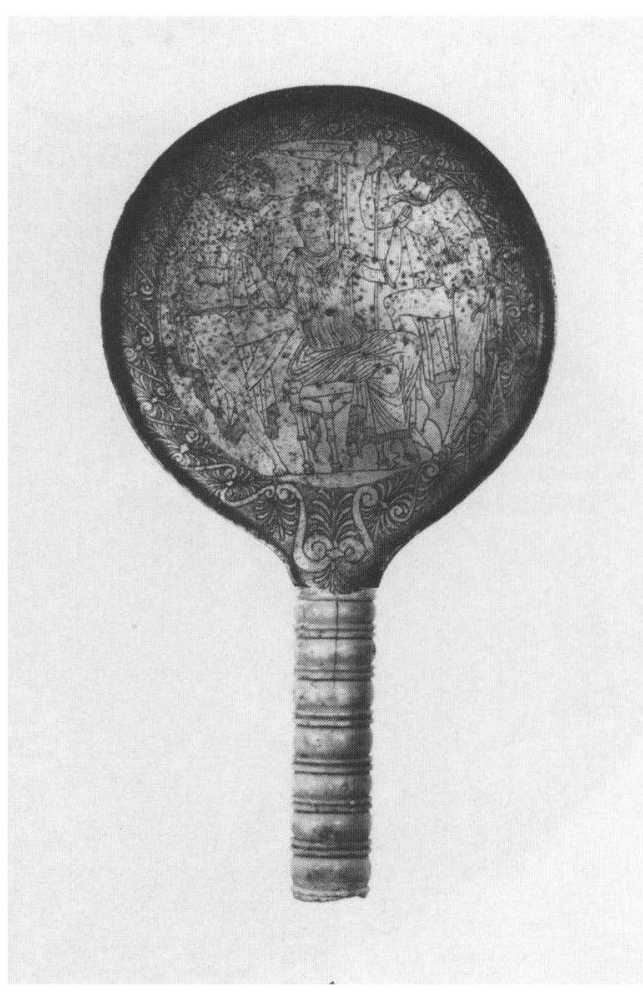

(b) Etruscan bronze mirror (I I).

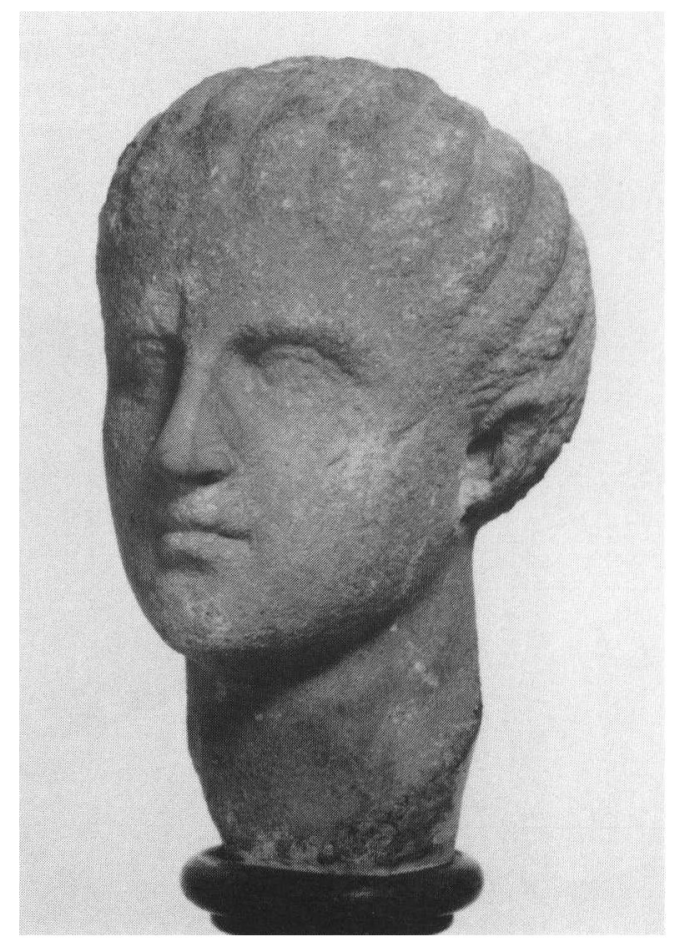

(d) Marble head of girl (I s). 
JHS cx (1990)

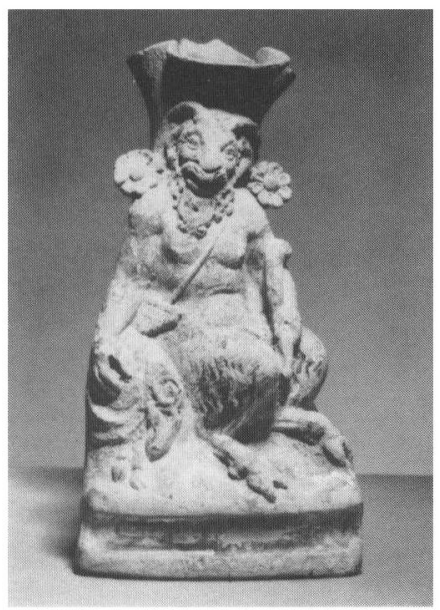

(a) Attic oinochoe in the form of Pan (22).

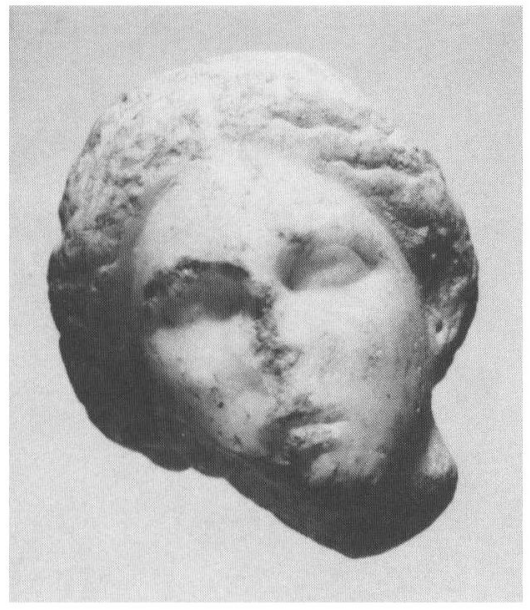

(c) Marble head of Aphrodite (?) (I6).

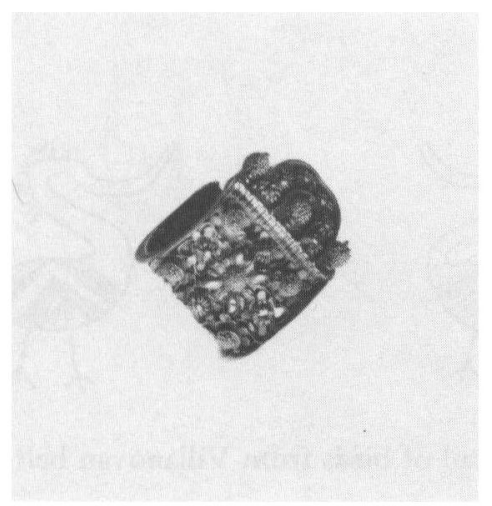

(e) Etruscan gold earring (3).

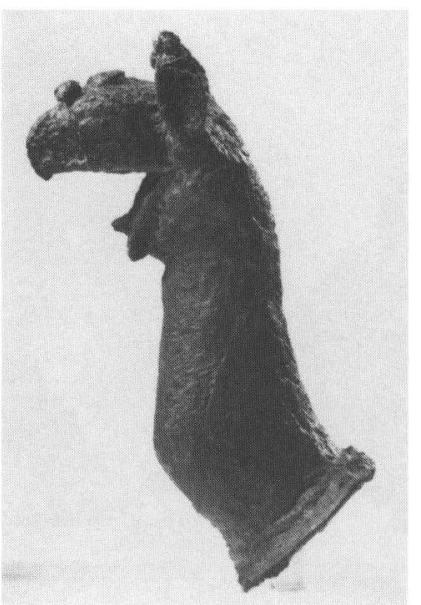

(b) East Greek bronze griffin protome (4).

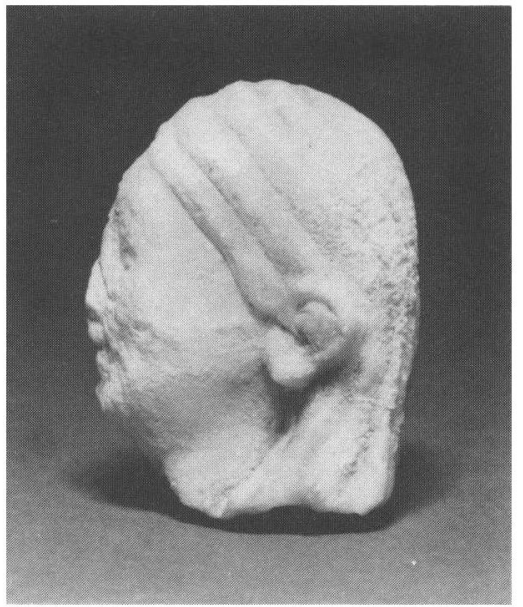

(d) Naucratite alabaster head from kouros (14).

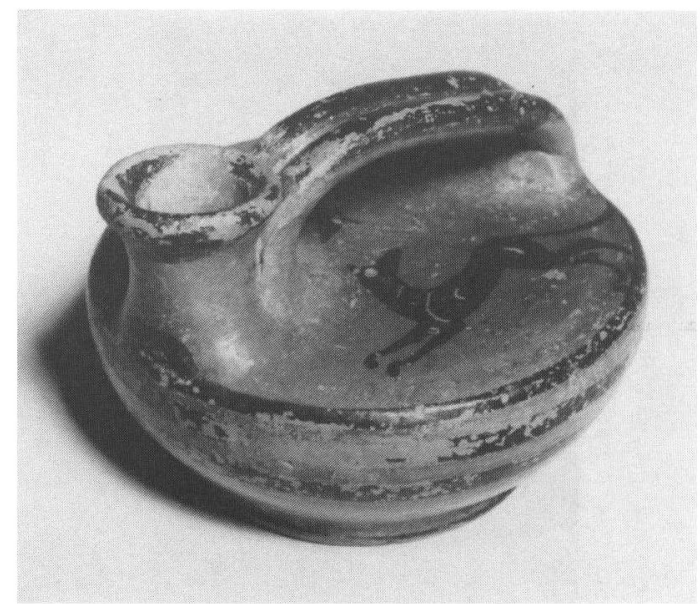

(f) East Greek black-figured askos (17). 


\section{PLATE VIII}

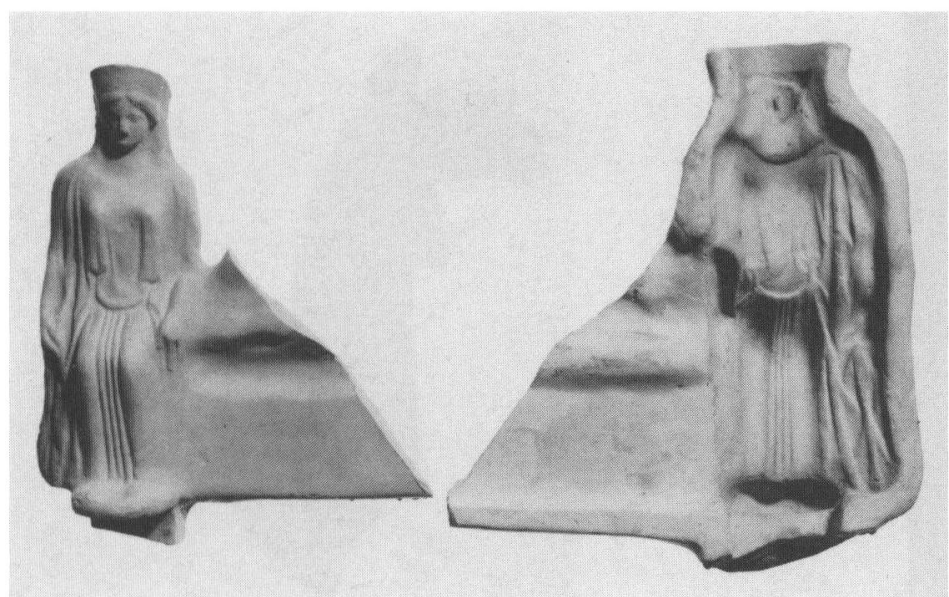

(a) Tarantine terracotta mould with modern impression (32).
JHS cx (1990)

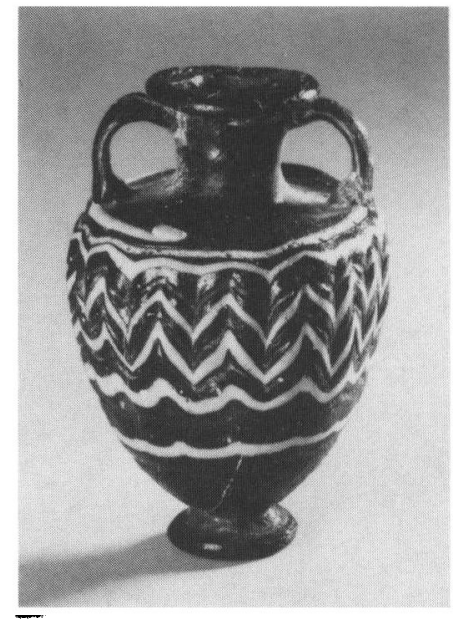

(c) Eastern Mediterranean glass amphoriskos (35).

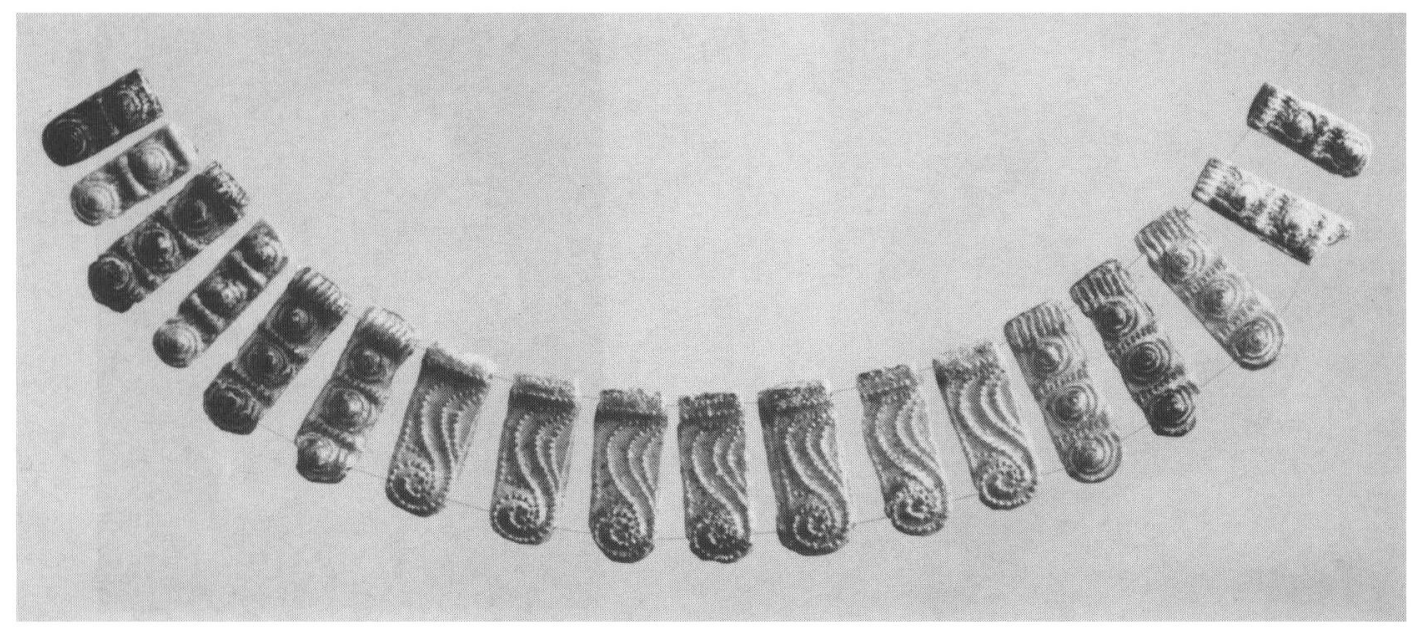

(b) Mycenaean moulded glass beads (34).
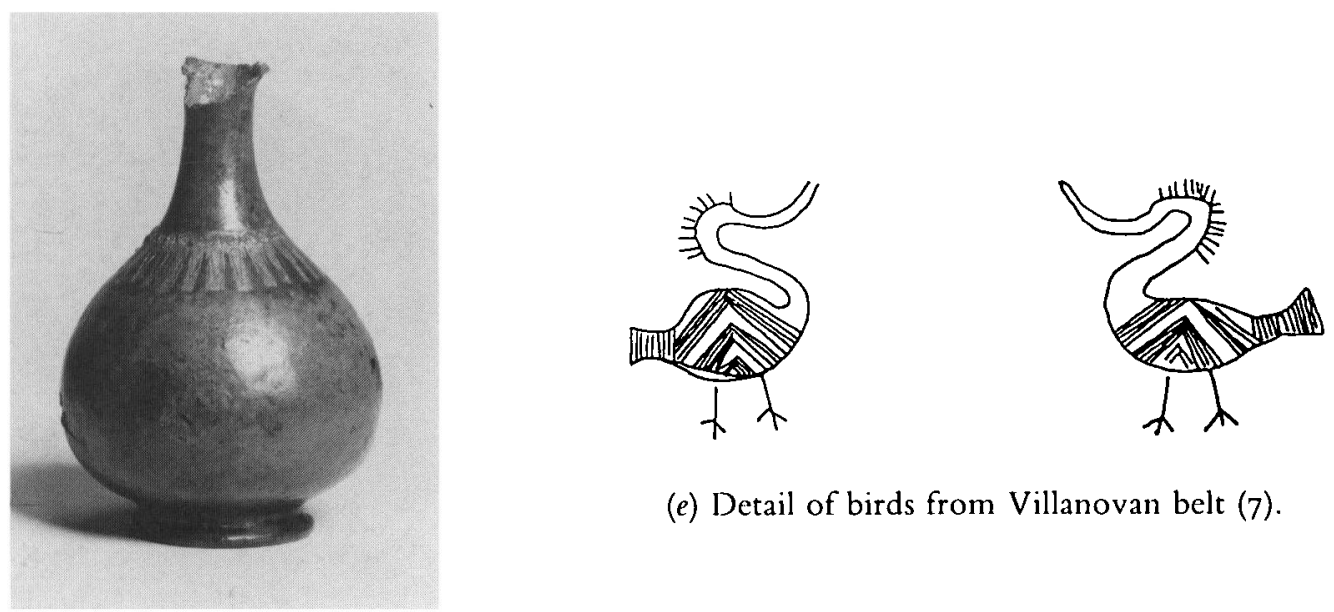

(e) Detail of birds from Villanovan belt (7).

(d) Tarantine (?) silver perfumed-oil container (I). 


\title{
THE SOCIETY FOR THE PROMOTION OF HELLENIC STUDIES
}

\author{
31-34 GORDON SQUARE, LONDON WC1H OPP
}

\section{HONORARY MEMBERS}

\author{
Akurgal, Prof. E., Ankara, Turkey. \\ Amandry, Prof. Pierre, Paris, France. \\ Andronicos, Prof. M., Thessaloniki, Greece. \\ Burkert, Prof. Dr W., Uster, Zürich, Switzerland. \\ Daux, Prof. G., Paris, France. \\ Dow, Prof. S., Cambridge, Mass, U.S.A. \\ Karageorghis, Dr V., Nicosia, Cyprus. \\ Karouzou, Mrs S. P., Athens, Greece. \\ Kassel, Prof. R., Cologne, Germany. \\ Knox, Prof. B. M. W., Darnestown, Maryland, U.S.A. \\ Kunze, Dr E., Grosshesselohe bei München, Germany. \\ Neugebauer, Prof. O., Princeton, New Jersey, U.S.A. \\ Platon, Dr N., Athens, Greece. \\ Pugliese Carratelli, Prof. G., Rome, Italy. \\ Romilly, Prof. J. de, Paris, France. \\ Sambursky, Prof. S., Jerusalem, Israel. \\ Thompson, Mrs D. B., Princeton, New Jersey, U.S.A. \\ Thompson, Prof. Homer A., Princeton, New Jersey, U.S.A. \\ Trendall, Prof. A. D., Bundoora, Victoria, Australia. \\ Trypanis, Prof. C., Kifissia, Athens, Greece. \\ Vernant, Prof. J.-P., Sèvres, France. \\ Vian, Prof. F., Versailles, France. \\ Vlastos, Prof. G., Berkeley, California, U.S.A. \\ Will, Prof. E., Nancy, France. \\ Winnington-Ingram, Prof. R. P., London. \\ Zakythinos, Prof. D. A., Athens, Greece.
}

\section{CORPORATE MEMBERS}

Agelef Shipping Co. (London) LtD

BANK OF CYPRUS (LONDON) LTD

Capeside Steamship Company Ltd

Chandris (LONDON) LTD

EPIROTIKI LINES (LONDON) LTD

HadjIPATERAS MaRITIME LTD

JOANNOU \& PARASKEVAIDES (UK) LTD

JOHN C. HADJIPATERAS \& SONS LTD

LEVENTIS OVERSEAS LTD
Olympic Maritime Carriers (Europe) LtD

PAPACHRISTIDIS LTD

Prgasus Ocean Services Ltd

RETHYMNIS \& KULUKUNDIS LTD

SOUTHERN SHIPPING (CHARTERING) LTD

STAKIS plc

SWan Hellenic

Victoria STEAmship Co LTD

Mr \& MrS Nicholas EGON

\section{Hellenic and Roman Societies \\ SLIDES COLLECTION}

The Slides Collection contains over 6,000 coloured slides $(35 \mathrm{~mm})$, covering a wide variety of subjects, including sites on the Greek mainland, the Greek islands, Cyprus, Rome, Italy and the Roman Empire, Etruscan tomb paintings, Roman frescoes and mosaics and Greek vases.

Individual slides, sets and filmstrips may be hired by members, and some filmstrips are available for purchase.

Details of current charges may be obtained from the Librarian at 31-34 Gordon Square, London WCIH OPP. 


\section{The Society for the Promotion of Hellenic Studies}

\section{1-34 GORDON SQUARE, LONDON WCIH OPP}

President: Professor J. P. Barron

The Society, founded in 1879 to advance the study of Greek language, literature, history and art, maintains conjointly with the Society for the Promotion of Roman Studies and in association with the Institute of Classical Studies of the University of London:

1. A Library of some 65,000 volumes, with c. 450 current periodicals

2. Some 6,000 coloured slides covering a wide variety of subjects, set of slides with lecture texts, and film strips.

Books and slides can be sent to Members by post. Communications about books and slides should be addressed to the Librarian at the above address.

Four general meetings, with lectures, are held in London annually. Other meetings in different parts of the country are arranged in collaboration with local branches of the Classical Association.

Subscribers receive the Society's two annual publications: The Journal of Hellenic Studies, one of the foremost British periodicals in the field of Greek scholarship, containing articles, illustrations and book reviews; Archaeological Reports, a fully illustrated account of fresh discoveries in Greece and Greek lands, with bulletins announcing important new acquisitions by museums in Britain.

These two periodicals are on sale to the general public.

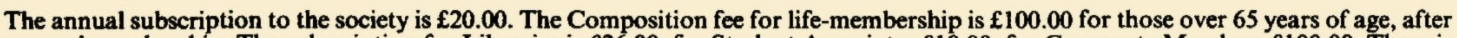
five years' membership. The subscription for Libraries is $£ 26.00$, for Student Associates $£ 10.00$, for Corporate Members $£ 100.00$. There is no entrance fee.

All enquiries to the Secretary. Telephone 071-387 7495

\section{The Society for the Promotion of Roman Studies}

31-34 GORDON SQUARE, LONDON WC1H OPP

President: Professor F. G. B. Millar D.LITT., FBA. FSA

The Society was formed in 1910 to promote the study of the archaeology, art, literature, and history of Italy and the Roman Empire down to about the year A D 700. It publishes annually the Journal of Roman Studies containing articles by leading scholars and reviews of recent publications. The society also publishes Britannia, a journal of Romano-British and connected studies, which includes an annual survey of Romano-British excavations.

The Society maintains with the Hellenic Society and in conjunction with the London University Institute of Classical Studies a joint library of works on classical antiquity and a collection of slides and film strips. Members resident in or visiting the U.K. may borrow books and slides and consult books belonging to the Institute. Meetings of the Society are held in London and in other parts of the U.K. together with other societies. Triennial conferences with the Hellenic Society and the Classical Association are held in either Oxford or Cambridge.

Annual subscriptions. Members and Schools, $£ 20.00$ for either the $J R S$ or Britannia ( $£ 35.00$ for both). Institutions other than Schools, $£ 25.00$ for each publication. Students of U.K. and Commonwealth Universities $£ 10.00$. Life membership for members with five years' membership and of age 65 or over, $£ 100.00$.

All enquiries to the Secretary. Telephone 071-387 8157

\section{HELLENIC SOCIETY PUBLICATIONS}

All prices include postage and packing. Members of the Society are offered a $10 \%$ discount. New members and associates will be offered a $20 \%$ discount in their first year of membership. Dollar rates cover bank and negotiation charges.

\section{Back Numbers}

JOURNAL OF HELLENIC STUDIES (with ARCHAEOLOGICAL REPORTS) from 1965

Volumes Ixxxv (1965) to c (1980)

Volumes ci (1981) to cvi (1986)

Volumes cvii (1987) to cix (1989)

(Supplied with Archaeological Reports where stocks permit)

Volumes $33(1986 / 87)-35(1988 / 89)$

\section{Supplementary Papers}

9. THE GREEK ANTHOLOGY: SOURCES AND ASCRIPTIONS by A. S. F. Gow

11. EURIPIDES AND THE JUDGEMENT OF PARIS by T. C. W. Stinton

12. THE SANTORINI VOLCANO AND THE DESOLATION OF MINOAN CRETE by D: L. Page

13. EAST GREEK INFLUENCE ON ATTIC VASES by D. A. Jackson

14. ATTIKA $\rightarrow$ STUDIES IN ATHENIAN SCULPTURE OF THE HELLENIC AGE by Andrew Stewart

Orders should be addressed to: The Secretary, Hellenic Society, 31-34 Gordon Square, LONDON WC1H OPP

\section{THE CLASSICAL ASSOCIATION}

The main aims of the Classical Association are to promote and sustain interest in classical studies, to maintain their rightful position in universities and schools and to give scholars and teachers opportunities of meeting and discussing their problems. It organises an annual conference, lasting four or five days, in a university centre, and sponsors over 30 branches, which arrange programmes of lectures and discussions and many of which hold Greek and Latin Reading Competitions for Schools. Its activities are fully reported in its annual Proceedings, issued free to all members.

The present membership of the Association is approximately 4,000. Membership is open both to individuals and to institutions (annual subscription. $£ 3.00$ life subscription, for individuals only, $£ 63.00$ ). Members may obtain the Classical Review and Classical Quarterly at reduced prices (Review, $£ 13.00$; Quarterly, $f 14.00$; combined subscription $£ 24.00$ ). Greece and Rome may also be obtained through the Association for an annual subscription of $\mathbf{f 1 1 . 0 0}$. Applications for membership and subscriptions for the journals (which should normally be received by January 31 st in each year) should be addressed to the Treasurer, Mr R. Wallace, Dept. of Classics, The University, Keele, Staffs ST5 SBG.

The Association can also supply copies of the Index to the First Series of the Classical Review (price for members, $f 1.50$ post free) and of the last issue of The Year's Work in Classical Studies, covering the years 1945-47 (price $£ 1.00$, post free). These publications and details of the various oecasional publications of the Association, including all Supplements to Greece and Rome, are obtainable from the Treasurer. Inquiries, other than about membership and publications, should be sent to either of the Secretaries (Professor J. Percival, Dept. of Classics), University College, P.O. Box 78, Cardiff CF1 IXL, and Miss H. M. Jones, 20 Lowestoft Rd., Watford, Herts WD2 5AX.

Contributions to the Journal should be sent to Prof. A. H. Sommerstein, Dept. of Classics, University of Nottingham, Nottingham NG7 2RD. Good photocopies, not original typescripts, should be submitted. For style of references to be adopted see this isene pp. 295-296 (ofiprint available free from the Secretary, Hellenic Society, 31-34 Gordon Square, London WC1H 0PP: 071-387 7495).

Books intended for review should be addressed to the Librarian, Hellenic Society,

31-34 Gordon Square, London WC1H 0PP. The Journal does not accept unsolicited book reviews.

Printed by Stephen Austin and Sons Ltd. Hertford 